\title{
Chemical Composition and Biological Activities of Essential Oils from Fresh Vismia guianensis (Aubl.) Choisy and Vismia cayennensis (Jacq.) Pers. Leaves
}

Composição química e atividades biológicas dos óleos essenciais das follhas de Vismia guianensis

(Aubl.) Choisy e Vismia cayennensis (Jacq.) Pers.

Composición química y actividades biológicas de los aceites esenciales de hojas de Vismia

guianensis (Aubl.) Choisy y Vismia cayennensis (Jacq.) Pers.

Received: 06/21/2021 | Reviewed: 06/29/2021 | Accept: 06/30/2021 | Published: 14/07/2021

\author{
Antonia Tavares Barbosa \\ ORCID: https://orcid.org/0000-0002-8441-2699 \\ Universidade Federal do Amazonas, Brazil \\ E-mail: antoniatavares92@hotmail.com \\ Vitor Hugo Neves da Silva \\ ORCID: https://orcid.org/0000-0002-1184-2241 \\ Universidade Federal do Amazonas, Brazil \\ E-mail: hugor_ns@hotmail.com \\ BrunaYuka Koide da Silva \\ ORCID: https://orcid.org/0000-0002-5228-7520 \\ Universidade Federal do Amazonas, Brazil \\ E-mail: brunaykoide@gmail.com \\ Aniele da Silva Neves Lopes \\ ORCID: https://orcid.org/0000-0002-3830-9631 \\ Universidade Federal do Amazonas, Brazil \\ E-mail: aniele.neves16@gmail.com \\ Isabel Reis Guesdon \\ ORCID: https://orcid.org/0000-0002-1372-250X \\ Universidade Federal do Amazonas, Brazil \\ E-mail: isabelbio@gmail.com \\ Paulo José Sousa Maia \\ ORCID: https://orcid.org/0000-0003-3101-3712 \\ Universidade Federal do Rio de Janeiro-Macaé, Brazil \\ E-mail: pmldcb@gmail.com \\ Maxwell Adriano Abegg \\ ORCID: https://orcid.org/0000-0002-0328-1122 \\ Universidade Federal do Amazonas, Brazil \\ E-mail: maxabegg@gmail.com \\ Geone M. Corrêa \\ ORCID: https://orcid.org/0000-0002-9458-8305 \\ Universidade Federal do Amazonas, Brazil \\ E-mail: geonemaia@ufam.edu.br \\ Dominique Fernandes de Moura do Carmo \\ ORCID: https://orcid.org/0000-0002-8835-1619 \\ Universidade Federal do Amazonas, Brazil \\ E-mail: dominiquefmc@ufam.edu.br
}

\begin{abstract}
The Vismia Vand. genus encompasses many species indigenous to the Amazon rain forest where they are popularly known as "Lacre" bark and leaves are widely employed by locals to treat dermatophytoses. The aim of this study was to investigate the chemical composition of essential oils (EOs) extracted from the aerial parts of the species Vismia guianensis (Aubl.) Choisy and Vismia cayennensis (Jacq.) Pers. and to assess their antimicrobial activity against the bacteria Staphylococcus aureus Rosenbach 1884 and Escherichia coli (Migula 1895) Castellani and Chalmers 1919 as well as the fungi Candida albicans (C.P. Robin) Berkhout 1923 and Candida parapsilosis (Ashford) Langeron \& Talice 1932. The analysis of the chemical composition of the essential oil extracted from V. guianensis leaves (EOVg) indicated 46 components, of which three sesquiterpenes predominated, namely: (E)-caryophyllene $(10.40 \%), \alpha$ copaene (29.45\%), and (E)-nerolidol (24.06\%). As to the essential oil from $V$. cayennensis leaves (EOVc), 61 components were identified, of which two oxygenated sesquiterpenes stood out as the main components, namely, germacrone $(25.42 \%)$ and curzerene $(25.29 \%)$. EOVg exhibited Minimum Inhibitory Concentration (MIC) of 1.56 $\mu \mathrm{g} / \mathrm{mL}$ against the yeast $C$. parapsilosis whereas EOVc was active against the bacteria $E$. coli and $S$. aureus as well as the yeast $C$. parapsilosis. The results obtained in this study strongly recommend further research on the essential oils
\end{abstract}


in question with a view to isolating and identifying the components responsible for their observed antimicrobial activities.

Keywords: Essential oils; Chemical compostition; Hypericaceae.

\section{Resumo}

O gênero Vismia Vand. apresenta espécies distribuídas na região amazônica, onde são conhecidas popularmente como "Lacre" e suas cascas e folhas são utilizadas no tratamento de dermatofitoses. Este trabalho objetivou realizar o estudo da composição química dos óleos essenciais das partes aéreas das espécies Vismia guianensis (Aubl.) Choisy e Vismia cayennensis (Jacq.) Pers. e avaliar a atividade antimicrobiana frente às bactérias Staphylococcus aureus Rosenbach 1884 e Escherichia coli (Migula 1895) Castellani and Chalmers 1919 bem como aos fungos Candida albicans (C.P. Robin) Berkhout 1923 e Candida parapsilosis (Ashford) Langeron \& Talice 1932. Sobre a composição química das amostras de óleo essencial (OE), foram identificados 46 constituintes no óleo essencial da espécie V. guianensis (OEVg), destes, três foram identificados como majoritários, os sesquiterpenos: trans-cariofileno (10,40\%), $\alpha$ copaeno $(29,45 \%)$ e o trans-nerolidol $(24,06 \%)$. Na amostra de óleo essencial da espécie V. cayennensis (OEVc) foram identificados 61 constituintes, dos quais, destacaram-se dois sesquiterpenos oxigenados como constituintes majoritários, a germacrona $(25,42 \%)$ e o curzereno $(25,29 \%)$. O OEVg apresentou Concentração Inibitória Mínima (CIM) de 1,56 $\mu \mathrm{g} / \mathrm{mL}$ para cepas fúngicas da $C$. parapsilosis e o OEVc foi ativo para as bactérias $E$. coli e $S$. aureus e para a levedura $C$. parapsilosis. Os resultados obtidos sugerem o isolamento e identificação dos constituintes responsáveis pelas atividades observadas.

Palavras-chave: Óleo essencial; Composição química; Hypericaceae.

\section{Resumen}

El género Vismia Vand. tiene especies distribuidas en la Región Amazónica, donde se les conoce popularmente como "Lacre" y su corteza y hojas se utilizan en el tratamiento de la dermatofitosis. Este trabajo tuvo como objetivo estudiar la composición química de los aceites esenciales de las partes aéreas de las especies Vismia guianensis (Aubl.) Choisy y Vismia cayennensis (Jacq.) Pers. y evaluar la actividad antimicrobiana frente a las bacterias Staphylococcus aureus Rosenbach 1884 y Escherichia coli (Migula 1895) Castellani and Chalmers 1919 y los hongos Candida albicans (C.P. Robin) Berkhout 1923 y Candida parapsilosis (Ashford) Langeron \& Talice 1932. Sobre la composición química de las muestras de Aceite Esencial (AE), se identificaron 46 constituyentes en el aceite esencial de la especie $V$. guianensis (AEVg), de los cuales tres fueron identificados como principales sesquiterpenos trans-cariofileno $(10,40 \%), \alpha$ - copaeno $(29,45 \%)$ y trans-nerolidol $(24,06 \%)$. En la muestra de aceite esencial de la especie $V$. cayennensis (AEVc) se identificaron 61 constituyentes, de los cuales se destacaron dos sesquiterpenos oxigenados como constituyentes mayoritarios, germacrón $(25,42 \%)$ y curzereno $(25,29 \%)$. AEVg tuvo una Concentración Inhibitoria Mínima (CIM) de $1,56 \mu \mathrm{g} / \mathrm{mL}$ contra cepas fúngicas de $C$. parapsilosis y AEVc fue activo contra bacterias E. coli y $S$. aureus y contra la levadura $C$. parapsilosis. Los resultados obtenidos sugieren el aislamiento e identificación de los constituyentes responsables de las actividades observadas.

Palabras clave: Aceite esencial; Composición química; Hypericaceae.

\section{Introduction}

Essential oils from plants have been widely used in medicine, agriculture, perfumery, and cosmetics (Paolini, et al., 2010; Thuy, et al., 2021; Maia, et al., 2019; Křmonal, et al., 2015; Razavi, et al., 2021; Saikia, et al., 2020; Stojanović-Radić, et al., 2020). Several research groups are currently conducting studies on the chemical composition and biological potential of essential oils extracted from numerous plants, such as Vismia Vand. spp. (Simões et al., 2007). Vismia is an extensive genus of the Hypericaceae family, consisting of small trees inhabiting the tropical and subtropical regions of Central and South America (Hussain et al., 2012).

Notwithstanding the extensiveness of this genus, the literature provides scientific studies on essential oils from three Vismia species alone. Rojas et al. (2011) studied essential oils obtained from V. guianensis (Aubl.) Choisy fruit, V. baccifera Planch. \& Triana fruit, and V. macrophylla Kunth leaves and reported antimicrobial activity for V. baccifera var. dealbata (Kunth) Ewan against the microorganisms Enterococcus faecalis (Andrewes and Horder 1906) Schleifer and Kilpper-Bälz 1984, Staphylococcus aureus Rosenbach 1884, and Bacillus cereus Frankland and Frankland 1887, with MIC values ranging from 9 to $37 \mu \mathrm{g} / \mathrm{mL}$. Another study by Rojas et al. (2010) on the essential oil (EO) extracted from $V$. baccifera fruit pointed to broad-spectrum bactericide activity against Staphylococcus aureus, Enterococcus faecalis, Escherichia coli (Migula 1895) Castellani and Chalmers 1919, Pseudomonas aeruginosa (Schroeter 1872) Migula 1900, and Klebsiella pneumoniae (Schroeter 
1886) Trevisan 1887. By means of CG-EM analysis, the researchers identified 27 chemical components in V. baccifera EO, chiefly trans-cadin-1,4-diene, cis-cadin-1,4-diene, and $\beta$ - caryophyllene.

Additionally, Rojas et al. (2011) described the fungicide potential of Vismia essential oils, which supports the scientific community's interest in identifying the chemical components and assessing the pharmacological actions of this genus. In this vein, this study aimed at investigating the chemical profile and antimicrobial potential of essential oils extracted from V. guianensis and V. cayennensis (Jacq.) Pers. leaves against the microorganisms E. coli, S. aureus, Candida albicans (C.P. Robin) Berkhout 1923 and Candida parapsilosis (Ashford) Langeron e Talice 1932.

\section{Materials and method}

\subsection{Collection of plant samples}

Dry leaves from the aerial parts of the species under investigation were collected at several sites in Itacoatiara, Brazil: Vismia cayennensis $\left(03^{\circ} 05^{\prime} 36.9^{\prime \prime} \mathrm{S}, 058^{\circ} 27^{\prime} 44.7^{\prime \prime} \mathrm{W}\right.$ Gr longitude, and $\pm 5 \mathrm{~m}$ altitude) and V. guianensis $\left(03^{\circ} 05^{\prime} 39.8^{\prime \prime} \mathrm{S}\right.$, $058^{\circ} 27^{\prime} 43.8^{\prime \prime} \mathrm{W}$ Gr longitude, $\pm 4 \mathrm{~m}$ altitude). Then, the samples were identified and deposited at the herbarium collection of the Universidade do Estado do Amazonas, at the Centro de Estudos Superiores de Itacoatiara-CESIT (Voucher number 0055) and at the Instituto Nacional de Pesquisas da Amazônia-INPA (Voucher number 18448).

\subsubsection{Extraction of essential oils from Vismia guianensis and V. cayennensis leaves}

The essential oils from $V$. guianensis and $V$. cayennensis leaves were obtained by hydrodistillation of fresh material in a modified Clevenger-type apparatus coupled to a round bottom flask with distilled water $(5 \mathrm{~L})$ for approximately 4 hours. Next, the EO samples were centrifuged (3500 rpm) for 10 minutes for water/oil separation, which was done with a graduated micropipette. Extractions were performed in triplicate, with $800 \mathrm{~g}$ of fresh leaves of both Vismia species in each flask. Then, the EO samples were stored in Eppendorf tubes, sealed, and kept at $-4{ }^{\circ} \mathrm{C}$ until analysis and testing. The samples of $V$. guianensis and $V$. cayennensis EOs were coded as EOVg and EOVc, respectively.

\subsubsection{Gas chromatography coupled to mass spectrometry (GC/MS)}

The obtained essential oils underwent analysis in a SHIMADZU gas chromatographer coupled to a SHIMADZU QP2010 mass spectrometer (GC-MS). For component chromatography, a $30 \mathrm{~m} \times 0.25 \mathrm{~mm}$ DB-5MS column with $0.25 \mu \mathrm{m}$ inner film thickness was employed. The chemical components were identified by interpreting their respective mass spectra, calculating their Kovats Indexes (KIs), and matching them up to data found in the literature. The calculated KIs were then compared to those tabulated for isolated compounds by Adams (2007).

\subsection{Biological assays}

\subsubsection{Antimicrobial assay}

The antimicrobial activity test was carried out at the Microbiology Laboratory of the Exact Sciences and Technology Institute (ICET/UFAM), using the microplate dilution test to analyze the antibacterial and antifungal potential of OEVg and OEVc.

\subsubsection{Microorganisms}

The EO samples underwent antimicrobial susceptibility tests in vitro according to the protocol described in the literature (Vaz et al., 2009), using a panel with ATCC strains (American Type Culture Collection, USA). The antibacterial 
activity of the essential oils was assessed against the Gram-positive bacterium Staphylococcus aureus (ATCC 25923), Gramnegative bacterium Escherichia coli (ATCC 25922), and fungi Candida albicans (ATCC 10231) and Candida parapsilosis (ATCC 22019).

\subsubsection{Preparation and standardization of microbial inoculums}

The bacterial and fungal strains were grown in Mueller Hinton broth for $24 \mathrm{~h}$ at $37{ }^{\circ} \mathrm{C}$ and standardized by adding sterile PBS ( $\mathrm{pH}$ 7.2) until obtaining turbidity equal to that of the suspension in the 0.5 tube on the McFarland scale (approximately $1.0 \times 10^{8} \mathrm{CFU} / \mathrm{mL}$ ). Then, a spectrophotometric reading was performed at $620 \mathrm{~nm}$ to confirm the microorganism concentration. Subsequently, small amounts of bacterial and fungal strains were removed, with the aid of a sterile loop, and added to $5 \mathrm{~mL}$ of sterile LB broth and $5 \mathrm{~mL}$ of YPD broth for the bacteria and fungi in question, respectively. The microorganism concentration was confirmed by spectrophotometer reading.

\subsubsection{Preparation of EO samples}

Firstly, a 10\% dimethyl-sulfoxide (DMSO) solution was prepared by diluting DMSO (100 $\mu \mathrm{L})$ in sterile distilled water $(900 \mu \mathrm{L})$. Then the EOVg and EOVc samples were diluted in 10\% DMSO by solubilizing the samples (10 $\mathrm{mg}$ ) in the previously prepared solvent $(100 \mu \mathrm{L})$. Through this procedure, stock solutions of each sample were prepared to a concentration of $100 \mu \mathrm{g} / \mathrm{mL}$. The assays were performed on five 96-well ELISA microplates, which were divided as follows:

1. The wells used validating the method and measurement of results were identified as "positive and negative controls": the positive control comprised the culture medium, bacterial or fungal suspension and the reference antimicrobial standard whereas the negative control consisted of the culture medium and 10\% DMSO;

2. Wells identified as "blank" contained the culture medium and the essential oil of each sample in order to eliminate the turbidity caused by its color when evaluating the results; and

3. Wells identified as "assay" contained the culture medium, a mixture of essential oil with DMSO, and the bacterial or fungal suspension.

\subsection{Determination of the Minimum Inhibitory Concentration (MIC)}

\subsubsection{Microdilution for bacteria}

MIC was performed in triplicate at 1:2 concentration. The bacteria under investigation were E. coli and S. aureus. Chloramphenicol and 10\% DMSO were employed as reference standard (positive control) and negative control, respectively. The 96 microplate wells were filled with the LB broth $(100 \mu \mathrm{L})$. Then, in the first well, $100 \mu \mathrm{L}$ of the EO stock solution was added prepared initially in concentration at $100 \mu \mathrm{g} / \mathrm{mL}$. After a serial dilution was conducted in the seven consecutive wells, removing $100 \mu \mathrm{L}$ from the highest concentration well, resulting in a solution of up to $0,39 \mu \mathrm{g} / \mathrm{mL}$. The assay was performed in triplicate for each concentration. Likewise, the LB broth $(50 \mu \mathrm{L})$ plus Chloramphenicol $(50 \mu \mathrm{L})$ were added to the positive control whereas the LB broth $(50 \mu \mathrm{L})$ plus $10 \%$ DMSO $(50 \mu \mathrm{L})$ were added to the negative control, in triplicate. Finally, the microorganism suspensions $(10 \mu \mathrm{L})$ were added to every well and incubated for 24 hours at $37^{\circ} \mathrm{C}$.

\subsubsection{Microdilution for fungi}

MIC was performed in triplicate for C. albicans and C. parapsilosis with methanol (positive control) and 10\% DMSO (negative control) as reference standard. The microplate wells were filled with the YPD broth (100 $\mu \mathrm{L})$. Then, in the first well, $100 \mu \mathrm{L}$ of the EO stock solution was added prepared initially in concentration at $100 \mu \mathrm{g} / \mathrm{mL}$. After a serial dilution was conducted in the seven consecutive wells, removing $100 \mu \mathrm{L}$ from the highest concentration well, resulting in a solution of up to 
$0,39 \mu \mathrm{g} / \mathrm{mL}$. The YPD broth $(50 \mu \mathrm{L})$ plus methanol $(50 \mu \mathrm{L})$ were added to the positive control whereas the YPD broth $(50 \mu \mathrm{L})$ plus $10 \%$ DMSO $(50 \mu \mathrm{L})$ were added to the negative control, in triplicate. Then, the microorganism suspensions $(10 \mu \mathrm{L})$ were added to the wells and incubated for $48 \mathrm{~h}$ at $37^{\circ} \mathrm{C}$. After incubation, a visual reading and a reading with Resazurin dye (100 $\mu \mathrm{g} / \mathrm{mL}$ ) of the microbial growth were performed.

\section{Results and discussion}

\subsection{Yields}

Table 1 shows the variation in yields of EOVg and EOVc. EOVg yield was higher in September/2019 (0.04\%), a period of intense drought, and lower yield in November/2019 (0.03\%), the rainy season in the region. EOVc exhibited a yield of $0.54 \%$ in the dry season, a satisfactory value as compared to that obtained for EOVg during the same period. The difference between the yield values may be attributed to several factors, e.g., temperature, rainfall, place and time of sample collection, which can have critical effects on both the quantity and quality of essential oils.

Table 1. Yields of essential oils extracted from fresh Vismia cayennensis and V. guianensis leaves.

\begin{tabular}{|c|c|c|c|c|c|}
\hline Plant sample & Year/month & Temperature & Sample code & Plant mass (g) & Yield \\
\hline \multirow{2}{*}{ V. guianensis } & $\begin{array}{c}\text { September } \\
2019\end{array}$ & $32{ }^{\circ} \mathrm{C}$ & \multirow{2}{*}{$\mathrm{EOVg}$} & $800 \mathrm{~g}$ & $0.04 \%$ \\
\hline & $\begin{array}{c}\text { November } \\
2019\end{array}$ & $30{ }^{\circ} \mathrm{C}$ & & $800 \mathrm{~g}$ & $0.03 \%$ \\
\hline \multirow{2}{*}{ V. cayennensis } & $\begin{array}{c}\text { September } \\
2019\end{array}$ & $35^{\circ} \mathrm{C}$ & \multirow{2}{*}{ EOVc } & $800 \mathrm{~g}$ & $0.54 \%$ \\
\hline & $\begin{array}{c}\text { November } \\
2019\end{array}$ & $30{ }^{\circ} \mathrm{C}$ & & $800 \mathrm{~g}$ & $0.24 \%$ \\
\hline
\end{tabular}

* EOVg: Essential oil from Vismia guianensis; EOVc: Essential oil from V. cayennensis. Source: Authors.

The lower yields of the essential oils during the rainy season may be due to lixiviation, i.e., continuous rain may result in loss of hydro-soluble substances in leaves and roots. This may apply to plants that produce alkaloids, glycosides, and even volatile oils (Evans, 1996; Walterman \& Mole 1994).

\subsubsection{Chemical composition of essential oils}

The analysis of the chemical composition of OEVg revealed 46 components, of which sesquiterpenes were the most common ones (63.91\%): (E)-caryophyllene (10.40\%), $\alpha$-copaene (29.45\%), and (E)-nerolidol (24.06\%). OEVc presented 61 chemical components, in which a high proportion $(50.71 \%)$ of oxygenated sesquiterpenes was found: germacrone $(25.42 \%)$ and curzerene $(25.29 \%)$. The chemical profile of both essential oils showed a high percentage of sesquiterpenes, mostly hydrocarbon sesquiterpenes. For example, $V$. guianensis has $\alpha$-humulene $(2.84 \%), \beta$-selinene $(0.79 \%)$, $\alpha$-guaiene $(0.16 \%)$, cyperene $(0.20 \%), \alpha$-selinene $(1.14 \%), \alpha$-muurolene $(0.23 \%)$, and $\delta$-cadinene $(2.27 \%)$ as well as two oxygenated sesquiterpenes, namely, caryophyllene oxide $(0.88 \%)$ and viridiflorol $(0.41 \%)$. In addition to this class of metabolites, hydrocarbon monoterpenes, such as $\alpha$-pinene $(0.09 \%)$ and $\beta$-pinene $(0.08 \%)$, and other components were identified, albeit in lesser quantities (Table 2). 
Table 2. Substances found in Vismia guianensis EO.

\begin{tabular}{|c|c|c|c|c|c|}
\hline Substance & Class & Area \% & RT & $\mathbf{K} \mathbf{I}_{\text {cal }}$ & $\mathbf{K} \mathbf{I}_{\text {tab }}$ \\
\hline$\alpha$-pinene & HM & 0.09 & 4.971 & 932 & 932 \\
\hline$\beta$-pinene & HM & 0.08 & 6.091 & 977 & 974 \\
\hline a-copaene & HS & 29.45 & 21.361 & 1370 & 1374 \\
\hline Cyperene & HS & 0.20 & 22.461 & 1397 & 1398 \\
\hline (E)-caryophyllene & HS & 10.40 & 23.154 & 1414 & 1417 \\
\hline$\alpha$-guaiene & HS & 0.16 & 23.830 & 1430 & 1437 \\
\hline a-humulene & HS & 2.84 & 24.621 & 1450 & 1452 \\
\hline B-panasinsene & HS & 0.26 & 25.520 & 1472 & 1381 \\
\hline$\beta$-selinene & HS & 0.79 & 25.980 & 1483 & 1489 \\
\hline$\alpha$-selinene & HS & 1.14 & 26.267 & 1490 & 1498 \\
\hline$\alpha$-muurolene & HS & 0.23 & 26.425 & 1494 & 1500 \\
\hline$\beta$-bisabolene & HS & 0.63 & 26.836 & 1504 & 1505 \\
\hline$\delta$-cadinene & HS & 2.27 & 27.185 & 1513 & 1522 \\
\hline Sesquisabinene & HS & 1.59 & 27.447 & 1519 & 1457 \\
\hline (E)-nerolidol & OS & 24.06 & 28.989 & 1557 & 1561 \\
\hline Caryophyllene alcohol & OS & 0.29 & 29.385 & 1567 & 1570 \\
\hline Caryophyllene oxide & OS & 0.88 & 29.616 & 1572 & 1482 \\
\hline Guaiol & OS & 0.74 & 30.240 & 1588 & 1600 \\
\hline Viridiflorol & OS & 1.04 & 30.493 & 1594 & 1582 \\
\hline Copaborneol & $\mathrm{OM}$ & 1.41 & 30.689 & 1598 & NI \\
\hline Agarospirol & OS & 2.80 & 31.289 & 1613 & 1646 \\
\hline Cadina-1(6),4-diene <trans> & OS & 0.94 & 31.957 & 1630 & 1461 \\
\hline Cadin-4-eno-7-ol <cis> & OS & 0.89 & 32.035 & 1632 & 1635 \\
\hline$\alpha$-muurolol & OS & 0.62 & 32.135 & 1634 & 1644 \\
\hline Intermedeol & $\mathrm{OM}$ & 2.04 & 32.531 & 1644 & 1665 \\
\hline$\alpha$-bisabolol & OS & 1.39 & 33.615 & 1670 & 1385 \\
\hline Total & & 87.23 & & & \\
\hline
\end{tabular}

RT: Retention Time; $\mathrm{KI}_{\text {cal }}$ : Calculated Kovats Index; $\mathrm{KI}_{\mathrm{tab}}$ : Tabulated Kovats Index; NI: Not Identified; HS: Hydrocarbon Sesquiterpene; OS: Oxygenated Sesquiterpene; OM: Oxygenated Monoterpene; HM: Hydrocarbon Monoterpene. Source: Adams (2017).

The analysis of the EOVc indicated the presence of hydrocarbon monoterpenes, such as $\alpha$-pinene $(0.08 \%)$, sabinene $(0.04 \%)$, myrcene $(0.24 \%)$, limonene $(0.10 \%)$, and terpinolene $(0.02 \%)$. Higher percentages were found for hydrocarbon sesquiterpenes, e.g., as (E)-carophyllene (2.15\%), and $\beta$-selinene $(0.42 \%)$, as well as oxygenated sesquiterpenes, e.g., viridiflorol $(0.45 \%)$, spatulenol $(0.86 \%)$, and carophyllene oxide $(0.97 \%)$. Likewise, small percentages of other components were identified, as shown in Table 3. 
Table 3. Substances found in Vismia cayennensis EO.

\begin{tabular}{|c|c|c|c|c|c|}
\hline Substance & Class & Area \% & RT & $\mathbf{K I}_{\text {cal }}$ & $\mathbf{K I}_{\text {tab }}$ \\
\hline$\alpha$-pinene & HM & 0.08 & 4.93 & 931 & 932 \\
\hline Sabinene & HM & 0.04 & 6.067 & 976 & 969 \\
\hline Myrcene & HM & 0.24 & 6.330 & 987 & 988 \\
\hline Limonene & HM & 0.10 & 7.581 & 1038 & 1024 \\
\hline$\beta$-fandandrene & HM & 0.05 & 7.642 & 1040 & 1025 \\
\hline (Z)- $\beta$-ocimene & HM & 0.21 & 8.124 & 1060 & 1044 \\
\hline terpinolene & $\mathrm{OM}$ & 0.02 & 9.516 & 1116 & 1086 \\
\hline$\delta$-elemene & HS & 0.33 & 19.698 & 1329 & 1335 \\
\hline (E)-caryophyllene & HS & 2.15 & 23.159 & 1414 & 1417 \\
\hline$\alpha$-humulene & HS & 0.22 & 24.626 & 1450 & 1452 \\
\hline germacrene-D & HS & 0.76 & 25.670 & 1476 & 1484 \\
\hline$\beta$-selinene & HS & 0.42 & 25.980 & 1483 & 1489 \\
\hline curzerene & OS & 25.29 & 26.290 & 1491 & 1499 \\
\hline muurolene & HS & 0.20 & 26.434 & 1494 & 1500 \\
\hline$\gamma$-cadienene & OS & 0.42 & 27.192 & 1513 & 1513 \\
\hline spathulenol & OS & 0.85 & 29.455 & 1568 & 1577 \\
\hline germacrone & OS & 25.42 & 32.742 & 1644 & 1693 \\
\hline caryophyllene oxide & OS & 0.97 & 29.622 & 1572 & 1482 \\
\hline viridiflorol & OS & 2.44 & 29.799 & 1577 & 1592 \\
\hline cubeban-11-ol & - & 0.96 & 30.221 & 1587 & 1595 \\
\hline Rosifoliol & OS & 0.45 & 31.259 & 1612 & 1600 \\
\hline$\delta$-cadinene & HS & 0.54 & 31.968 & 1630 & 1522 \\
\hline cadin-4-eno-7-ol $\langle c i s\rangle$ & HS & 0.98 & 32.049 & 1632 & 1635 \\
\hline$\alpha$-muurolol & HS & 0.30 & 32147 & 1634 & 1500 \\
\hline hexadienoic acid & - & 0.88 & 32.365 & 1631 & NI \\
\hline intermedeol & $\mathrm{OM}$ & 5.28 & 32.560 & 1642 & 1665 \\
\hline naphthalenol & - & 0.40 & 32.930 & 1649 & NI \\
\hline $1,2,4,5$ tetramethyl-[2,4] heptane & - & 0.48 & 33.406 & 1666 & NI \\
\hline (E)- $\gamma-$-bisabolene & HS & 0.73 & 42.589 & 1890 & 1529 \\
\hline Total & & 71.21 & & & \\
\hline
\end{tabular}

RT: Retention Time; $\mathrm{KI}_{\text {cal }}$ : Calculated Kovats Index; $\mathrm{KI}_{\mathrm{tab}}$ : Tabulated Kovats Index; NI: Not Identified; HS: Hydrocarbon Sesquiterpene; OS: Oxygenated Sesquiterpene; OM: Oxygenated Monoterpene; HM: Hydrocarbon Monoterpene. Source: Adams (2017).

Sesquiterpenes preponderate in essential oils from most Vismia spp. Rojas et al. (2011) describe three sesquiterpenes as the main components in a sample of $V$. baccifera EO, i.e., cadina-1,4-diene <trans> (36.6\%), cadina-1,4-diene $<$ cis>(18.8\%), and $\beta$-caryophyllene (11.9\%). They also identified $\beta$-caryophyllene (20.1\%), germacrone D (11.6\%), and $\beta$ elemene $(7.0 \%)$ in a sample of essential oil extracted from $V$. macrophylla leaves. Monoterpenes and sesquiterpenes have been depicted as biologically active in the literature. Lima et al. (2005), investigating the action of the monoterpenes $\alpha$-pinene and $\beta$ pinene, found satisfactory activity against C. albicans, C. tropicalis (Castell.) Berkhout, C. parapsiolisis, C. stellatoidea (C.P. 
Jones \& D.S. Martin) Langeron \& Guerra, C. krusei (Castell.) Berkhout, and Cryptococcus neoformans (San Felice) Vuill. In a previous study carried out by Peñuelas et al. (2005), monoterpenes were shown to have thermotolerance, photoprotection, and antioxidant properties due their ability to capture oxygen radicals produced during photosynthesis. On the other hand, sesquiterpenes have been highlighted in several essential oils due to their strong odor and anti-inflammatory and antifungal power (Zheng et al., 1992).

\subsection{Biological activity}

\subsubsection{Microdilution assay for fungi and bacteria}

The literature indicates remarkable antimicrobial activity in essential oils from Vismia spp. According to Pérez and colleagues (2011) and Montanari and colleagues (2011), essential oils extracted from V. macrophylla fruit are active against Gram-positive (S. aureus and E. fecalis) and Gram-negative (E. coli) bacteria, with MIC values ranging from $150 \mu \mathrm{L} / \mathrm{mL}$ to $740 \mu \mathrm{L} / \mathrm{mL}$. Those studies also observed antimicrobial activity in the essential oil extracted from leaves of the same species, effective against the Gram-positive bacteria S. aureus $(100 \mu \mathrm{L} / \mathrm{mL})$ and $E$. faecalis $(500 \mu \mathrm{L} / \mathrm{mL})$ as well as against the fungi $C$. albicans and C. krusei (600 $\mu \mathrm{L} / \mathrm{mL}$ each). Screening results for antifungal and antibacterial activities are depicted in table 4 .

Table 4. Antibacterial and antifungal activities (MIC values in $\mu \mathrm{g} / \mathrm{mL}$ ) of OEVg and OEVc.

\begin{tabular}{c|c|c|c|c|c}
\hline \multirow{2}{*}{ Species } & \multirow{2}{*}{ Essential oils } & \multicolumn{2}{|c|}{ Bacterial strains } & \multicolumn{2}{c}{ Fungal strains } \\
\cline { 3 - 6 } & & SA & EC & CA & CP \\
\hline V. guianensis & EOVg & $>1000$ & $>1000$ & $>1000$ & 1.56 \\
\hline V. cayennensis & EOVc & 25 & 50 & $>1000$ & 50 \\
\hline
\end{tabular}

*EOVg: Essential oil from Vismia guianensis; EOVc: Essential oil from V. cayennensis; SA: Staphylococcus aureus (ATCC 25923); EC: Escherichia coli (ATCC 25922); CA: Candida albicans (ATCC 10231); CP: Candida parapsilosis (ATCC 22019). Source: Authors.

OEVg inhibited fungal growth of $C$. parapsilosis strains at $1.56 \mu \mathrm{g} / \mathrm{mL}$ concentration. As stated by Holetz et al. (2002), samples with MIC values below $100 \mu \mathrm{g} / \mathrm{mL}$ are classified as very active, i.e., they strongly inhibit microbial growth. MIC values between 100 and $500 \mu \mathrm{g} / \mathrm{mL}$ denote satisfactory antimicrobial activity. Values between 500 and $1000 \mu \mathrm{g} / \mathrm{mL}$ indicate moderate activity whereas those above $1000 \mu \mathrm{g} / \mathrm{mL}$ imply poor inhibitory activity. In this study, OEVg exhibited strong antimicrobial activity against the strains under investigation.

Silvestre et al. (2012), investigating the essential oil extracted from $V$. guianensis fruit, reported antimicrobial activity against S. lentus (Kloos et al. 1976) Schleifer et al. 1983 (MIC equal to $78 \mu \mathrm{g} / \mathrm{mL}$ ). Their research also identified $\beta$ caryophyllene (25.8\%), $\alpha$-copaene (13.1\%), and $\delta$-cadinene (11.6\%) as the main components.

The main components of OEVg were (E)-caryophyllene sesquiterpenes (10.40\%), $\alpha$-copaene (29.45\%), and (E)nerolidol (24.06\%). According to previous research, sesquiterpenes function as antimicrobial agents (CITÓ et al., 2003). The mechanism is still unclear, but it has been speculated that the lipophilic compounds found in this essential oil bind to and rupture the membrane of some microorganisms (COWAN, 1999). Reinsvold et al. (2011) showed that (E)-caryophyllene acts against microorganisms and, thus, can be used as antibiotic. This compound can also function biochemically as an anesthetic, anti-inflammatory, and spasmolytic drug. Other authors have reported antimicrobial activity of (E)-caryophyllene in kidney cell culture (RC-37), supporting its use as a prospective antimicrobial agent (Astani, 2009; Reichling \& Schnitzler 2009).

Another study by Gelinski et al. (2007) indicates that (E)-nerolidol acts as a limited-spectrum antibiotic as it is not effective against some bacteria such as Salmonella Lignieres 1900 sp., E. coli, and Proteus Hauser 1885 sp. This finding 
corroborates the results obtained in this study, i.e., the inactivity of OEVg against the bacteria E. coli and S. aureus as well as against the yeast $C$. albicans, probably due this this essential oil having this sesquiterpene as one of its main components.

The sesquiterpene $\alpha$-copaene is one of the main components of copaiba oil (Copaifera L. sp.). Studies have already shown that this oil can inhibit the growth of bacteria (Blose, 2003; Biavatti et al., 2006; Veiga \& Pinto, 2002) and fungi (Craveiro et al., 1981; Wang, 2000; Souza et al., 2005). The microbial inhibitory capability of this oil is attributed to $\alpha$ copaene.

OEVc exhibited strong inhibition against the bacteria $E$. coli and $S$. aureus at concentrations of $50 \mu \mathrm{g} / \mathrm{mL}$ and 25 $\mu \mathrm{g} / \mathrm{mL}$, respectively, and against the yeast $C$. parapsilosis at $50 \mu \mathrm{g} / \mathrm{mL}$ concentration. The main components identified in this essential oil are the oxygenated sesquiterpenes curzerene (25.29\%) and germacrone (25.42\%). Zhang and colleagues (2017) found curzerene to be one of the main components of the essential oil extracted from Curcuma phaeocaulis Valeton and attributed its observed antifungal activity $\left(\mathrm{IC}_{50}, 153.33-580.09 \mu \mathrm{g} / \mathrm{ml}\right)$ and inhibition of bacterial growth $\left(\mathrm{IC}_{50}, 485.00-778.33\right.$ $\mu \mathrm{g} / \mathrm{ml}$ ) to this sesquiterpene.

Another research conducted by Ogunwande et al. (2005) identified curzerene (19.7\%) and germacrone (27.5\%) as the main components of essential oils extracted from fruit and leaves of Curcuma phaeocaulis, respectively. The same study reports strong antibacterial activity for the essential oil extracted from Eugenia uniflora L. fruit and leaves against $S$. aureus and Bacillus cereus, respectively, with MIC equal to $39 \mu \mathrm{g} / \mathrm{mL}$. In addition to treating cancer and hepatitis, other studies indicate that germacrone can be employed as an antimicrobial agent (Wang et al., 2000).

\section{Conclusion}

The findings of this study are relevant in that they show the antimicrobial potential of EOVg and EOVc against some microorganisms, namely, C. parapsilosis (EOVg and EOVc), E. coli (EOVc), and S. aureus (EOVc). This antimicrobial action can be explained by the presence, in large quantities, of some components in the plant species under investigation. The prevailing sesquiterpenes in EOVg — i.e., (E)-caryophyllene (10.40\%), $\alpha$-copaene (29.45\%), and (E)-nerolidol (24.06\%) — as well as the main components found in OEVc - i.e., germacrone $(25.42 \%)$ and curzerene $(25.29 \%)$ - have demonstrated antimicrobial action. With the aim of addressing the paucity of information about essential oils from $V$. guianensis and $V$. cayennensis, this study has contributed their chemical profiles, indicated their antimicrobial potential, and, thus, provided a basis for future research with a view to isolating and characterizing the compounds responsible for the biological activities of OEVg and EOVc.

\section{Acknowledgments}

The authors would like to acknowledge Programa de Pós-Graduação em Ciência e Tecnologia para Recursos Amazônicos (PPGCTRA - UFAM), Fundação de Amparo à Pesquisa do Estado do Amazonas - FAPEAM (process $n^{\circ}$. 001/2021 - Mulheres na Ciência). We are also grateful to the Herbarium from INPA and CESIT for the kindly support, Coordenação de Aperfeiçoamento de Pessoal de Nível Superior - Brasil (CAPES) and Conselho Nacional de Desenvolvimento Científico - CNPq.

\section{References}

Adams R.P. (2007). Identification of Essential Oils Components by Gas Chromatography/Mass Spectroscopy. EUA: Allured Publishing Corporation, p. 804.

Aligiannis, N., Kalpoutzakis, E., Mitaku S., \& Chinou, I. B. (2001). Composition and antimicrobial activity of the essential oils of two Origanum species. Journal of agricultural and food chemistry, 49, 4168-4170. https://doi.org/10.1021/jf001494m. 
Astani, A., Reichling, J., \& Schnitzler P. (2009). Screening for Antiviral Activities of Isolated Compounds from Essential Oils. Evid Based Complement Alternat Med, 2011, 1-7. https://doi.org/10.1093/ecam/nep187.

Belltti, N., Ndagijimana, M., Sisto, C., Guerzoni, M. E., Lanciotti, R., \& Gardini, F. (2004). Evaluation of the antimicrobial activity of citrus essences on Saccharomyces cerevisiae. Journal of Agricultural and Food Chemistry, 52: 6932-6938. https://doi.org/10.1021/jf049444v.

Biavatti, M. W., Dossin, D., Deschamps, F. C., \& Lima, M. D. P. (2006). Análise de óleos-resinas de copaíba: contribuição para o seu controle de qualidade. Revista Brasileira de Farmacognosia, 16 (2), 230-235. http://dx.doi.org/10.1590/S0102-695X2006000200017.

Bloise, M. I. (2003). Óleos vegetais e especialidades da floresta Amazônica. Cosmetics \& Toiletries 15(5): 46-49.

Buitrago, A., Rojas, J., Rojas, L., Velasco, J., Morales, A., Peñaloza, Y., \& Díaz, C. (2015). Essential Oil Composition and Antimicrobial Activity of Vismia macrophylla Leaves and Fruits Collected in Táchira-Venezuela. Natural Product Communications, 10(2), 375-382. https://doi.org/10.1177\%2F1934578X1501000244.

Cardoso, P. R (2011). Estruturas secretoras em plantas. Programa de Pós Graduação em Biodiversidade Vegetal e Meio Ambiente, São Paulo.

Citó, A. M. G. L., Souza, A. A., Lopes, J. A. D., Chaves, M. H., Costa, F. B., Sousa, S. A. A., \& Amaral, M. P. M. (2003). Resina de Protium heptaphyllum March (Burceraceae): Composição química do óleo essencial e avaliação citotóxica frente à Artemia salina Leach. Anais da Associação Brasileira de Química, 52(2), 74-76.

Cowan, M. M. (1999). Plant products as antimicrobial agents. Clinical microbiology reviews, 12(4), 564-582.

Craveiro, A. A., Fernandes, A. G., Andrade, C. H. S., Matos, F. J. A., Alencar, J. W., \& Machado, M. I. L (1981). Óleos essenciais de plantas do nordeste. Fortaleza: Editora UFC. 210p.

Evans, W. C. (1996). Trease and Evans' Pharmacognosy, (14a ed.), WB Saunders Company: cap. 7.

Gelinski, J. M. L. N., Dalla Rosa, J. C., Paravisi, E. D.F. A., Baratto, C. M. (2007). Atividade antibacteriana do óleo essencial de Baccharis dracunculifolia DC (Asteraceae) e de seu composto ativo nerolidol em combinação ao EDTA ou lisozima. Evidência, 7(2), 131-144.

Gobbo-Neto, L., \& Lopes, N. P. (2007). Medicinal plants: factors of influence on the content of secondary metabolites. Química Nova, 30(2), 374-381. http://dx.doi.org/10.1590/S0100-40422007000200026.

Holetz, F. B., Pessini, G. L., Sanches, N. R., Cortez, D. A. G., Nakamura, C. V., \& Dias Filho, B. P. (2002). Screening of some plants used in the Brazilian folk medicine for the treatment of infectious diseases. Memórias do Instituto Oswaldo Cruz, 97(7),1027-1031. http://dx.doi.org/10.1590/S007402762002000700017

Hidayat Hussain, J. H., Al-Harrasi, A., Saleem, M., Green, I. R., Ree, T. V., \& Ghulam, A. (2012) Chemistry and biology of genus Vismia. Pharmaceutical Biology, 50, 1448-1462. https://doi.org/10.3109/13880209.2012.680972

Křumal, K., Kubátková, N., Večeřa, Z., \& Mikuška, P. (2015). Antimicrobial properties and chemical composition of liquid and gaseous phases of essential oils. Chemical Papers, 69, 1084-1092. https://doi.org/10.1515/chempap-2015-0118.

Lima, I. O., Oliveira, R. D. A. G., Lima, E. D. O., Souza, E. L. D., Farias, N. P., \& Navarro, D. D. F. (2005). Inhibitory effect of some phytochemicals in the growth of yeasts potentially causing opportunistic infections. Brazilian Journal of Plarmaceutical Sciences, 41(2), 199-203. http://dx.doi.org/10.1590/S151693322005000200007

Madigan, M., \& Martinko, J. (2004). The Bacteria. In: Brock- Biology of Microorganisms. Prantice Hall, 718-814.

Maia, P. J. S., Cruz, J. F., Augusto, F. A. de F., Santos, S. de F. F., \& Souza, E. A. (2019). Photophysical properties of a perylene derivative for use as catalyst in ethanol electrooxidation. Research on Chemical Intermediates, 45, 5451-5472. https://doi.org/10.1007/s11164-019-03911-3

Marinho, L. C., Ely, C. V., \& Amorim, A. M. (2017). Flora das cangas da Serra dos Carajás, Pará, Brasil: Hypericaceae. Rodriguésia, 68, 979-986. http://dx.doi.org/10.1590/2175-7860201768333

Martins, M. V., Shumizu, G. H., \& Bittrich, V. (2018). Flora da Reserva Ducke, Estado do Amazonas, Brasil: Hypericaceae. Hoehnea, 45(3), 361-371. https://doi.org/10.1590/2236-8906-13/2018

Montanari, R. M., Barbosa, L. C., Demuner, A. J., Silva, C. J., Carvalho, L. S., \& Andrade, N. J. (2011). Chemical composition and antibacterial activity of essential oils from Verbenaceae species: Alternative sources of (E)-caryophyllene and germacrene-D. Química Nova,34(9), 1550-1555. https://doi.org/10.1590/S0100-40422011000900013

Ogunwande, I. A., Olawore, N. O., Ekundayo, O., Walker, T. M., Schmidt, J. M., \& Setzer, W. N. (2005). Studies on the essential oils composition, antibacterial and cytotoxicity of Eugenia uniflora L. International journal of Aromatherapy, 15(3), 147-152. https://doi.org/10.1016/j.ijat.2005.07.004.

Paolini, J., Ouariachi, E. M. E., Bouyanzer, A., Hammouti, B., Desjobert, J. M., Costa, J., \& Muselli, A. (2010). Chemical variability of Artemisia herba-alba Asso essential oils from East Morocco. Chemical Papers, 64: 550-556. https://doi.org/10.2478/s11696-010-0051-5

Peñuelas, J., \& Munné-Bosch, S. (2005). Isoprenoids: an evolutionary pool for photoprotection. Trends in plant science, 10(4), 166-169. https://doi.org/10.1016/j.tplants.2005.02.005

Pérez-López, A., Cirio, A.T., Rivas-Galindo, V. M., Aranda, R.S., \& de Torres, N. W. (2011). Activity against Streptococcus pneumoniae of the essential oil and $\delta$-cadinene isolated from Schinus molle fruit. Journal of Essential Oil Research, 23(5): 25-28.https://doi.org/10.1080/10412905.2011.9700477 
Reinsvold, R. E., Jinkerson, R. E., Radakovits, R., Posewitz, M. C., \& Basu, C. (2011). The production of the sesquiterpene $\beta$-caryophyllene in a transgenic strain of the cyanobacterium Synechocystis. Journal of plant physiology. USA, 168(8), 848-852.https://doi.org/10.1016/j.jplph.2010.11.006

Razavi, F., \& Khajehsharifi H (2021) A colorimetric paper-based sensor with nanoporous SBA-15 for simultaneous determination of histidine and cysteine in urine samples. Chemical Papers. 75: 3401-3410 https://doi.org/10.1007/s11696-021-01548-4

Rojas, J., Buitrago, A., Rojas, L., \& Morales, A. (2011). Essential oil composition of Vismia macrophylla leaves (Guttiferae). Natural product communications, 6(1), 85-86. https://doi.org/10.1177\%2F1934578X1100600120

Saikia, S., Tamuli, K. J., Narzary, B., Banik, D., \& Bordoloi, M. (2020) Chemical characterization, antimicrobial activity, and cytotoxic activity of Mikania micrantha Kunth flower essential oil from North East India. Chemical Papers. 74, 2515-2528. https://doi.org/10.1007/s11696-020-01077-6

Silveira, J. C., Busato, N., Costa, A., \& Junior, E. C. (2012). Levantamento e análise de métodos de extração de óleos essenciais. Enciclopédia Biosfera, 8 (15), 2038-2052.

Silvestre, R. G., de Moraes, M. M., Lins, A. C., Ralph, M. T., Lima-Filho, J. V., Camara, C. A., \& Silva, T. M. (2012). Chemical composition, antibacterial and antioxidant activities of the essential oil from Vismia guianensis fruits. African Journal of Biotechnology, 11(41), 9888-9893. https://doi.org/10.5897/AJB11.3834

Simões, E. P., Schenkel, G., Gosmann, J. C. P., Mello, L. A. M., \& Petrovick, P. R. (2007). Farmacognosia: da planta ao medicamento. 6. ed.- Porto Alegre: Editora da UFRGS; Florianópolis: Editora da UFSC, p. 467-495.

Souza, E. L. D., Lima, E. D. O., Freire, K. R. D. L., \& Sousa, C. P. D. (2005). Inhibitory action of some essential oils and phytochemicals on the growth of various moulds isolated from foods. Brazilian archives of Biology and Technology, 48(2), 245-250. http://dx.doi.org/10.1590/S1516-89132005000200011

Stojanović-Radić, Z., Čomić, L., Radulović, N., Dekić, M., Ranđelović, V., \& Stefanović, O. (2010). Chemical composition and antimicrobial activity of Erodium species: E. ciconium L., E. cicutarium L., and E. absinthoides Willd. (Geraniaceae). Chemical Papers. 64, 368-377. https://doi.org/10.2478/s11696010-0014-X

Thuy, B. T. P., Hieu, L. T., My, T. T. A., Hai, N. T. T., Loan, H. T. P., Thuy, N. T. T., Triet, N. T., Anh, T. T. V., Dieu, N. T. X., Quy, P. T., Trung, N. V., Quang, D. T., Huynh, L. K., \& Nhung, N. T. A. (2021). Screening for Streptococcus pyogenes antibacterial and Candida albicans antifungal bioactivities of organic compounds in natural essential oils of Piper betle L., Cleistocalyx operculatus L. and Ageratum conyzoides L. Chemical Papers. 75, 1507-1519. https://doi.org/10.1007/s11696-020-01404-x.

Vaz, A. B., Mota, R. C., Bomfim, M. R. Q., Vieira, M. L., Zani, C. L., Rosa, C. A., \& Rosa, L. H. (2009). Antimicrobial activity of endophytic fungi associated with Orchidaceae in Brazil. Canadian journal of microbiology, 55(12), 1381-1391. https://doi.org/10.1139/W09-101.

Veiga Junior, V. F.; \& Pinto, A. C. (2002). O gênero copaifera L. Química nova, 25(2):273-286. http://dx.doi.org/10.1590/S0100-40422002000200016

Zhang, L., Yang, Z., Wei, J., Su, P., Pan, W., Zheng, X., \& Du, Z. (2017) Essential oil composition and bioactivity variation in wild-growing populations of Curcuma phaeocaulis Valeton collected from China. Industrial Crops and Products, 103,274-282. https://doi.org/10.1016/j.indcrop.2017.04.019

Zheng, G. Q., Kenney, P. M., \& Lam, L. K. (1992). Sesquiterpenes from clove (Eugenia caryophyllata) as potential anticarcinogenic agents. Journal of natural products, 55(7),999-1003. https://doi.org/10.1021/np50085a029.

Waterman, P. G., \& Mole, S. (1994). Analysis of phenolic plant metabolites, Blackwell Scientific Publications: Oxford, cap. 3.

Wang, H. K. (2000). The therapeutic potential of flavonoids. Expert opinion on investigational drugs, 9(9), 2103-2119. https://doi.org/10.1517/13543784.9.9.2103. 